\title{
Occurrence and morphological variability of Cylindrospermopsis raciborskii (WolOSZ.) SEENAYYA et SubBa RAJU (Cyanophyta, Nostocales) near Olomouc in 2006
}

\author{
Petr DVOŘÁK \& Petr HAŠLER
}

Department of Botany, Faculty of Science, Palacký University, Šlechtiteli̊ 11, CZ-783 71 Olomouc, e-mail: petr.hasler@upol.cz

\begin{abstract}
The presented paper focuses on the occurrence and variability of one of the most problematic cyanobacterium all over the world - Cylindrospermopsis raciborskii, which has occurred near Olomouc again after thirty years. We found the species in a small dead arm of the Morava River and collected samples of phytoplankton from summer to late autumn. We studied both living as well as preserved samples and documented variability of the species by drawings and microphotographs. The obtained data are discussed with relevant literature.
\end{abstract}

Key words: cyanobacteria, plankton, Cylindrospermopsis, the Morava River, morphology

The genus Cylindrospermopsis underwent several taxonomic transfers to its final establishment by SEENAYYA and RAJU in 1972. Cylindrospermopsis raciborskii was first described as Anabaena raciborskii by WOLOSZYŃSKA in 1912 and after that transferred into the genus Anabaenopsis by ELENKIN in 1923, who respected the terminal position of its heterocytes in contrast to the metameric structure of Anabaena filaments. Since 1923 other authors described related species of Anabaenopsis, but all of them did not take into account features of the genus concerning asymmetrical development of terminal heterocytes or trichome structure which are typical and well-distinguished. A lot of papers focusing on distribution, taxonomy, ecology and toxicology have been devoted to the genus Cylindrospermopsis and related genera (e.g. HiNDÁK 1988, KOMÁREK 2002, KOMÁREK \& KOMÁRKOVÁ 2003, STUKEN et al. 2006, DOS ANJOS et al. 2006). The genus occurs especially throughout tropical areas, where it usually forms well-developed populations and heavy water blooms. C. raciborskii was found to invade warm territories of Europe (Greece, Pannonian area and Ukraine) and recently Central Europe (Germany 2002, 2006).

In the Czech Republic or Czechoslovakia several records were made by HINDÁK (1988) and KOMÁREK and HORECKÁ (1979), who described occurrence of planktic populations of
C. raciborskii from SW Slovakia and SE Moravia. The only record near Olomouc was taken in 1978 at Chomoutov (KOMÁREK \& HORECKÁ 1979). Our locality is about $6 \mathrm{~km}$ away from Chomoutov and quite similar in regard to geology and hydrology. The species was found during our investigation of dead arms of the Morava River near Olomouc from August November. Environmental variables in this period were: conductivity $=464 \pm 85 \mu \mathrm{S} . \mathrm{cm}^{-1}$; temperature $=14.0 \pm 5.2^{\circ} \mathrm{C} ; \mathrm{pH}=9.3 \pm 0.12$. We used an Olympus BX60 light microscope and reference literature for species identification (GEITLER 1932, KONDATEVA 1968, KOMÁREK \& HORECKÁ 1979, HINDÁK 1988, KOMÁREK \& KOMÁRKOVÁ 2003).

Altogether 17 species of planktic cyanobacteria were found at the investigated site - Anabaena planctonica BRUNNTH., Anabaenopsis milleri WORONICHIN, Aphanizomenon gracile (LEMMERM.) LEMMERM., Aphanocapsa incerta (LEMMERM.) CRONBERG et KOMÁREK, Chroococcus limneticus LEMMERM., Cyanogranis ferruginea (WAWRIK) HINDÁK, Cylindrospermopsis raciborskii (WOLOSZ.) SEENAYYA et SUBBA RAJU, Microcystis aeruginosa (KÜTZ.) KÜTZ., M. ichthyoblabe KÜTZ., $M$. novacekii (KOMÁREK) COMPÈRE, $M$. wesenbergii (KOMÁREK) KOMÁREK, Oscillatoria janus SKUJA, Pannus spumosus B. HICKEL, Planktothrix agardhii (GOMONT) ANAGN. et KO- 
MÁREK, Pseudanabaena catenata LAUTERBORN, $P$. limnetica (LEMMERM.) KOMÁREK and Snowella litoralis (HÄYRÉN) KOMÁREK et HINDÁK. Cyanobacteria formed an important part of the phytoplankton with total of 6880 to 142690 cells. $\mathrm{ml}^{-1}$. However, warm areas are dominated by this species (22.7-98.6\%; CHAPMAN \& SCHELSKE 1997, TOTH \& PADISÁK 1986), C. raciborskii represents up to $10 \%$ of total biomass in our samples.

Morphology of $C$. raciborskii was found to be highly variable. Straight or bent filaments usually occurred, but no screw-like or coiled ones as described in previous literature (for detail see KOMÁREK \& KOMÁRKOVÁ 2003). The filaments were usually narrowed towards the ends and sometimes pointed. This feature disappeared when heterocytes and akinetes were developed at the terminal ends of tricomes. Vegetative cells with well-developed aerotopes were variable in length, but always longer than wide. We often found very long cells, almost ten times longer than wide (Tab. 1). Cell constrictions, if present, were not too deep. Oval to cylindrical akinetes with granular content usually occurred in number of 1 to 3 per filament, sometimes more. They developed at one end only. As filaments matured, the other akinetes developed at the opposite side and after that filament break usually followed (Fig. 1/A-H). Proheterocytes were formed by asymetrical division of terminal cell (Fig. 1/G) which metamorphosed into heterocytes of oval, conical to drop-like or curved shape (Fig. 1/I-N). Sometimes, unusual or extreme forms of long and sharply pointed heterocytes were also found. Extreme morphological variation was observed both in natural populations (KOMÁRKOVÁ et al. 1999) and cultures (SHAFIK et al. 2003) more likely affected by environmental variables (MOORE et al. 2004). Natural pupolution under our study showed similar variability, but cells were particularly longer than Lake Balaton populations (SHAFIK et al. 2003).

Table 1. Cell morphology of Cylindrospermopsis raciborskii natural population (Olomouc, Czech Republic).

\begin{tabular}{lccc}
\hline & $\begin{array}{c}\text { Vegetative } \\
\text { cell }\end{array}$ & Akinete & Heterocyte \\
\hline Length $[\mu \mathrm{m}]$ & $8-35$ & $9-27$ & $5-9$ \\
Width $[\mu \mathrm{m}]$ & $2-3(4)$ & $3-4(5)$ & $2-3$ \\
\hline
\end{tabular}

\section{Acknowledgement}

The authors are obliged to Dr. Eva Lelková for revising the English text and to grant NPGZ-M/03023 by the Ministry of Agriculture CR for supporting the project.

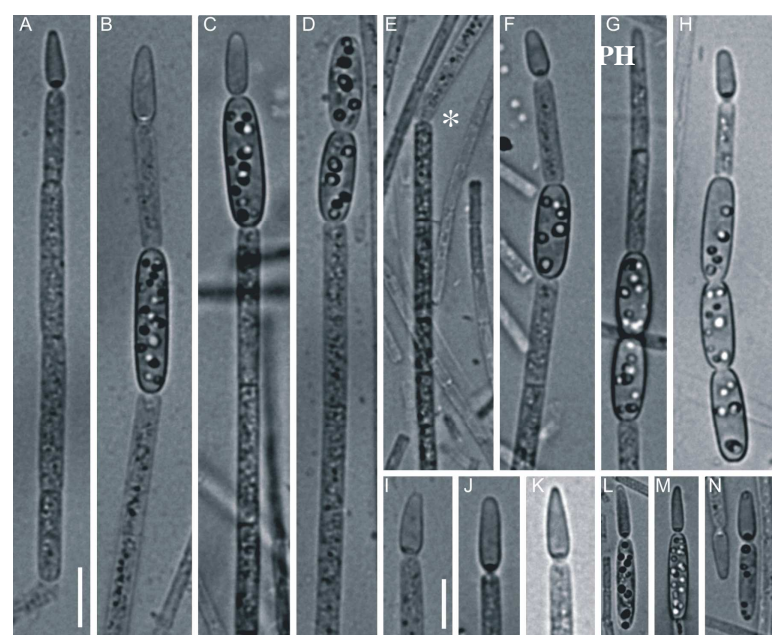

Fig. 1. Morphology of filaments of Cylidrospermopsis raciborskii. Asterisk - filament breaking, $\mathrm{PH}$ - proheterocyte formation. Scale bar $10 \mu \mathrm{m}$.

\section{References}

Berger, C., BA, N., Gugger, M., Bouvy, M., Rusconi, F., Coute, A., Troussellier, M. \& Bernard, C. (2006): Seasonal dynamics and toxicity of Cylindrospermopsis raciborskii in Lake Guiers (Senegal, West Africa). - FEMS Microbiol.Ecol. 57 (3): 355-366

Briand, J.F., Leboulanger, C., Humbert, J.F., Bernard, C. \& Dufour, P. (2004): Cylindrospermopsis raciborskii (Cyanobac-teria) invasion at midlatitudes: Selection, wide physiological tolerance, or global warming? - J.Phycol. 40(2): 231-238.

Chapman, A.D. \& Schelske, C.L. (1997): Recent appearance of Cylindrospermopsis (Cyano-bacteria) in five hypereutrophic Florida lakes. - J.Phycol. 33: 191-195.

dos Anjos, F.M., BitTencourt-Oliveira, M.D., Zajac, M.P., Hiller, S., Christian, B., ERLER, K., LuCKAS, B., PINTO, E. (2006): Detection of harmful cyanobacteria and their toxins by both PCR amplification and LC-MS during a bloom event. Toxicon 48(3): 239-245.

DRuART, J.C. \& BRIAND, J.F. (2002): First record of Cylindrospermopsis raciborskii (WOLOSZYNSKA) SEenayya et Subba Raju (Cyanobacteria) in a lotic system in France. - Ann. Limnol.- Int. J. Limnol. 38(4): 339-342.

HindÁK, F. (1988): Planktic species of two related genera Cylidrospermopsis and Anabaenopsis from Western Slovakia. - Arch. Hydrobiol. Suppl. 80(1-4)/ Algological Studies 50-53: 283-302. 


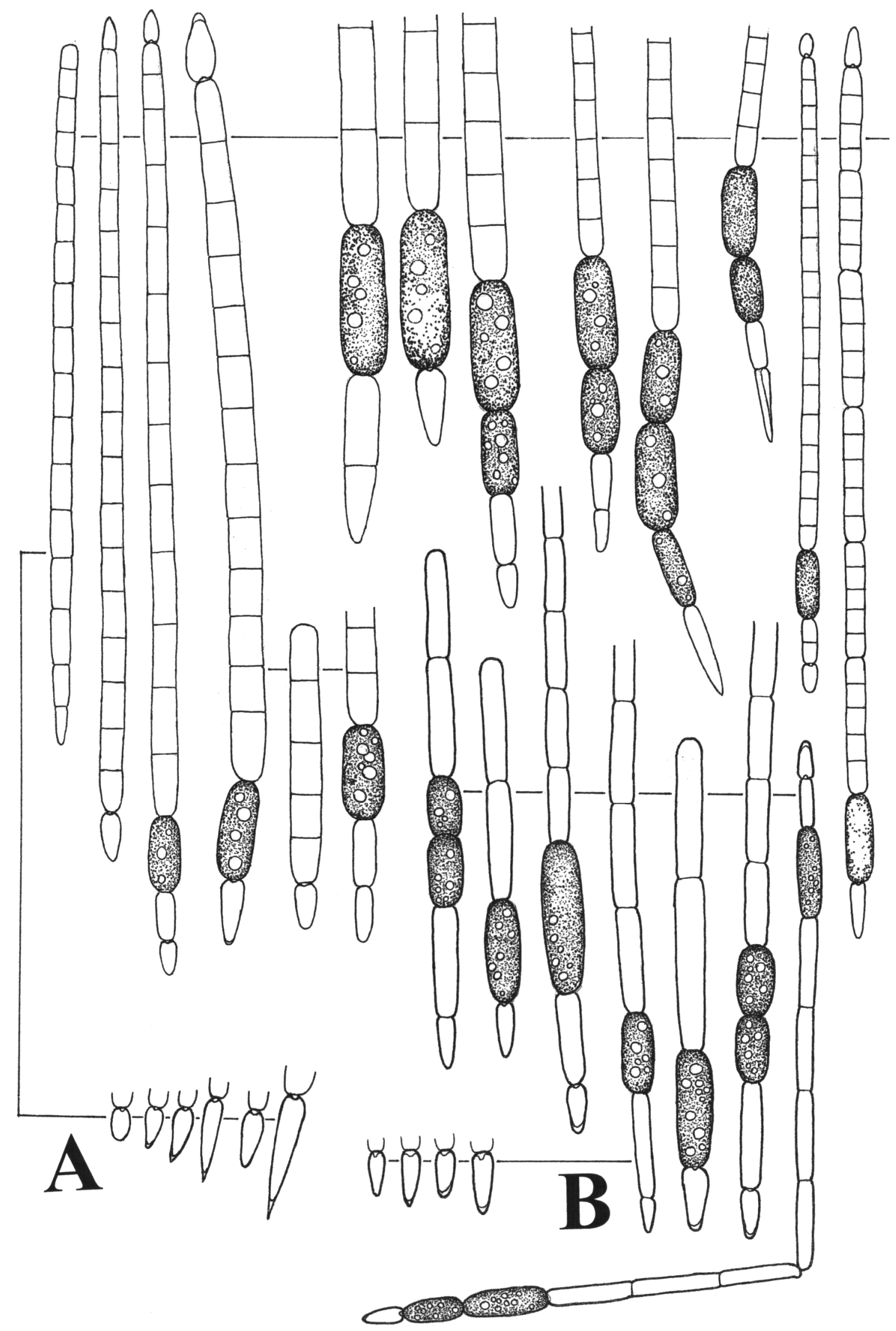

Fig. 2. Variability of C. raciborskii in phytoplankton near Olomouc: A - Hašler orig., B - Dvořák orig. 
HoreCKÁ, M. \& KoMÁREK, J. (1979): Taxonomic position of three planktonic blue-green algae from the genera Aphanizomenon and Cylindrospermopsis. - Preslia 51: 289-312.

KomÁREK, J. (2002): Problems in cyanobacterial taxonomy; implication for most common toxin producing species.- In: Melchiorre, S., Viaggiu, E. \& Bruno, M. (eds), Rapporti ISTISAN (Instituto Superiore di Sanitá), Roma 2000, 6-43 pp..

KomÁreK, J. \& KomÁrKovÁ-Legnerová, J. (2003): Phenotype diversity of the cyanoprokaryotic genus Cylindrospermopsis (Nostocales); review 2002. Czech Phycology 3: 1-30.

Moore, D., McGregor, G.B., Shaw, G. (2004): Morphological changes during akinete germination in Cylindrospermopsis raciborskii (Nostocales, Cyanobacteria). - J.Phycol. 40 (6): 1098-1105.

Shafik, H.M., Voros, L., Sprober, P., Presing, M., Kovacs, A.W. (2003): Some special morphological features of Cylindrospermopsis raciborskii in batch and continuous cultures. - Hydrobiologia 506 (1-3): 163-167.
Stuken, A., Rucker, J., Endrulat, T., Preussel, K., Hemm, M., Nixdorf, B., KARSTEN, U., Wiedner, C. (2006): Distribution of three alien cyanobacterial species (Nostocales) in northeast Germany: Cylindrospermopsis raciborskii, Anabaena bergii and Aphanizomenon aphanizomenoides. - Phycologia 45(6): 696-703.

Tотн, L. \& PAsisák, J. (1986): Meteorological factors affecting the bloom of Anabaenopsis raciborskii Wolosz. (Cyanophyta: Hormogonales) in the shallow Lake Balaton, Hungary. - J. Plank.Res. 8: 353-363.

Valerio, E., Pereira, P., SAKer, M.L., Franca, S. \& TENREIRO, R. (2005): Molecular characterization of Cylindrospermopsis raciborskii strains isolated from Portuguese freshwaters. - Harmful Algae 4(6): 1044-1052.

(C) Czech Phycological Society (2007)

Received December 12, 2006

Accepted February 27, 2007 